\title{
Selected Process Alternatives for Biomass Refining: A Review
}

\author{
Patricia Gullón, Enma Conde, Andrés Moure, Herminia Domínguez and Juan Carlos Parajó*
}

Department of Chemical Engineering, University of Vigo (Campus Ourense). As Lagoas. 32004 Ourense. Spain, and CITI-Tecnopole, San Ciprián de Viñas, Ourense, Spain

\begin{abstract}
The role of biorefineries in the production of energy and chemicals from biomass of lignocellulosic nature is reviewed. Special attention is devoted to biorefinery schemes dealing with the fractionation of lignocellulosic raw materials by chemical treatments. The potential of hydrothermal treatments as the first stage of future biorefineries is discussed. Special attention is devoted to the low-volume, high-added value products that can be solubilized by this type of technology.
\end{abstract}

Keywords: Biorefineries, lignocellulosic materials, cellulose, hemicelluloses, lignin.

\section{INTRODUCTION}

The material needs of society are reaching a crisis point, as the demand for resources will soon exceed the capacity of our present fossil resource based infrastructure [1]. The present situation poses a variety of social, economic and technological problems, including:

- the fear for a shortening of the supplies of basic resources,

- the population growth,

- the increasing per capita demands of the developing economies for goods and energy, derived from the increasing purchase power of the population,

- environmental challenges, specially those related to effects of greenhouse gas emissions (with particular emphasis on $\mathrm{CO}_{2}$ ) on the global climate,

- the national security issues surrounding reliance on imported oil [2], and particularly the desire for energy independence by many government worldwide, which is threatened by the geostrategic and political situation of some oil-producing countries.

In this context, the development of new process technologies enabling the replacement of oil-derived products by others derived from biomass that could fulfill the demand for energy and chemicals is essential [3]. Desirably, these new industrial processes should be based on domestic resources [2] and respect the "sustainable development" concept [4], opening opportunities for developing a biomass-based economy [5, 6] in a sustainable society [7].

In a broad sense, biomass refers to the whole set of materials with biogenic origin. However, for the purposes of this work, biomass refers to raw or processed vegetals, and

*Address correspondence to this author at the Department of Chemical Engineering, University of Vigo (Campus Ourense). As Lagoas. 32004 Ourense. Spain, and CITI-Tecnopole, San Ciprián de Viñas, Ourense, Spain; Tel: +34988387033: Fax: +34 9883 7001; E-mail: jcparajo@uvigo.es special interest is devoted to feedstocks of lignocellulosic nature (mainly made up of cellulose, hemicelluloses and lignin), which are here termed "lignocellulosic materials", LCM.

LCM can be classified according their origin in three categories:

- primary products from forest or agricultural sources (wood, straws, etc.),

- industrial byproducts (such as bagasses),

- waste materials (for example, urban solid wastes, residues from gardens and parks, etc.).

Considered as alternative raw material for processing, LCM show interesting features, including:

- huge availability, as LCM are the most abundant renewable resources in the world [7],

- renewable at a high generation rate (for example, about 1.3 billion dry ton of biomass, of which 368 billion dry ton coming from forest land, would be available in the US on an annual basis) [8]. This amount would be enough to produce biofuels to replace more than onethird of the current US demand for transportation fuels [8], even if in practical terms, biomass is expected to provide about $25 \%$ of the global requirements [9],

- disperse location, ensuring a secure and reliable supply [10],

- low cost, which could be even "negative" for some industrial wastes, if the disposal costs are considered,

- flexibility and versatility (in terms of the applicable conversion technologies and possible end-products), being able to be used for energy applications and chemicals currently satisfied from fossil resources,

- possibility of using the whole material in conversion processes [5],

- susceptibility to be transformed by environmentally friendly and sustainable processes based on the "green 
chemistry" principles [1-9], particularly in relation to a clean and efficient production [4],

- carbon-neutral [9], as the $\mathrm{CO}_{2}$ emitted when burning biomass is balanced by the $\mathrm{CO}_{2}$ captured as the plant biomass grows,

- their utilization as feedstocks is not competitive with food applications [11], as it happens with the production of first-generation bioethanol from starchy materials or sugarcane [12],

- strategic resource to reduce the emissions of fossil $\mathrm{CO}_{2}$ and support the rural economy [10].

Driven by the above ideas, the interest for converting biomass into chemicals and fuels is increasing, and a correspondent research effort is underway [13]. However, using biomass as a source of fuels and chemicals is hardly new. Burning biomass was the primary way of obtaining energy. Before the industrial revolution, the global economy was largely based on living carbon from plants [14], and the use of biomass for obtaining chemicals and energy was the norm for a large portion of chemicals produced prior to the twentieth century. In World War II, new technologies for biomass conversion into a variety of chemicals were developed. Today, European nations are using biomass from forestry and agricultural residues and municipal waste to produce heat and biopower, a field in which Finland is the leader (with 26 per cent of its primary energy coming from wood and peat). Competition between chemicals manufactured from biomass and fossil-based raw materials occurs at several levels, and current economically significant processes lead to the production of energy and chemicals from renewable resources $[9,15]$. The chemical industry has begun exploring biobased or renewable feedstocks for producing chemicals, but this transition to renewable feedstocks is impossible without the development of the appropriate technology and infrastructure.

LCM are difficult to be converted into chemical products due to their complex polymeric structures, requiring multidisciplinary approaches to achieve efficient commercial processes. Considering both the current robust forces driving sustainable production and the available biomass conversion technologies, biomass-based routes are expected to make a significant impact on the production of bulk chemicals within 10 years, and a huge impact within 20-30 years [16]. Biomass-derived commodities are expected to compete with commodities derived from fossil fuels in 20 years' time [17], enabling the sustainable production of bulk and fine chemicals, some of them as co- or by- products from fuel manufacture. A substitution potential of 10-15\% of fossil oil-based bulk chemicals by bio-based bulk chemicals, especially for oxygenated bulk chemicals, has been reported [16].

The industrial sectors need policy and legislation initiatives encouraging the development of new technologies that can allow biomass derived chemicals to become viable in the near future [18], particularly for setting stable framework conditions to provide security for investment decisions. This would be better achieved by building cognitive and sociopolitical legitimacy of the biorefining sector [18], by means of the design of market and communication strategies based on ecological aspects of biorefineries [19].

\section{TYPES OF BIOREFINERIES FOR LIGNOCELLU- LOSIC MATERIALS}

The term "biorefinery" has been coined to describe future processing complexes that will use biomass as feedstocks to produce a wide spectrum of chemicals, fuels and bio-based materials $[1,17,20]$, following a philosophy analogous to today's oil refineries, which produce multiple fuels and products from mineral oil. Biorefineries have been considered as the key for access to an integrated production of chemicals, materials, goods, fuels and energy of the future [21], enabling the development of a competitive bioeconomy that will be a key to sustainable industrial progress and economic growth in the XXI century [6]. This is expected to be achieved owing to the significance of the technological developments, which could result in a new manufacturing paradigm [22].

There are many biorefinery models, but all of them have to be based on an economically viable foundation [23]. Biorefineries have been proposed for processing grains (for example, first-generation ethanol plants can be considered as a preliminary model susceptible of further improvements) [2], proteinaceous materials and feedstocks of lignocellulosic nature. For the objectives of this work, this latter case is the most important, and the following paragraphs are focused on it.

Operation in biorefineries can be directed to obtain both high-value low-volume chemicals and low-value highvolume products, these latter particularly focused in the energy field $[5,9]$. Starting from LCM, these objectives can be accomplished through several approaches, including:

a. conversion of the feedstocks as a whole material, without previous separation of components, by means of physical, chemical and thermomechanical technologies [5], including gasification, liquefaction and pyrolysis [24], to yield products suitable for energy, synthesis of liquid fuels, conversion of chemicals and/or solid fuels of enhanced energy specific content. The "thermomechanical platform", including the "syngas platform" $[12,20]$, are representative examples of this type of technologies. The most prevalent emerging technology is gasification, followed by catalytic conversion of the synthesis gas to ethanol or other high-value products [12],

b. conversion of the feedstocks by physical, chemical and/or biotechnological methods based on the separation of "fractions" (extractives, cellulose, hemicelluloses, lignin), which can be further employed for different product application. The "sugar platform" $[12,20]$, based on the saccharification of LCM polysaccharides by chemical or enzymatic methods and further processing of the various process streams, is a representative example of this type of technologies. When polysaccharide hydrolysis is accomplished by enzymatic catalysis, the substrates have to be pretreated to increase their susceptibility to saccharification. Pretreatment is considered to be a central unit process in a biorefinery [25], and those of chemical nature have been considered to be the most promising. An effective pretreatment is necessary to achieve a good glucose yield in enzymatic hydrolysis [26].

Even though giving an exhaustive description of the chemicals that could be manufactured in biorefineries is out 
of the scope of this work, Figs. (1) to (3) present some representative examples highlighted in literature.

Fig. (1) develops some basic alternatives for the thermochemical conversion of LCM [27] by pyrolysis, liquefaction and gasification, including the postprocessing of synthesis gas to yield methanol and Fischer-Tropsch liquid fuels [3]. Fast pyrolysis of LCM leads to renewable solvents, monomers suitable as building blocks for polymers and other industrial chemicals [23]; whereas liquefaction leads to crude oils [28] which can yield chemicals upon refining.

Fig. (2) shows a general overview of LCM fractionation based on the selective solubilization of hemicelluloses (by hydrothermal processing in aqueous media, or by prehydrolysis with externally added mineral acids). Depending on the operational conditions, the hemicellulose solubilization step can be oriented towards the production of oligosaccharides (see below), fermentable hemicelulosic sugars, furfural or levulinic acid. Extractive-derived compounds appear in liquors, and can be recovered for refining or commercial purposes. The spectrum of products that can be derived from hemicellulosic sugar fermentation is broad, and includes the production of alcohols and acids. The cellulose contained in the spent solids from the hemicellulose solubilization step can be hydrolyzed with acids or enzymes to give fermentable glucose solutions and a solid phase mainly made up of lignin, which can be employed as fuel or as a substrate for gasification or pyrolysis. Fermentation of cellulose hydrolyzates can lead to a wide array of chemicals, from biofuels to

Thermochemical processing

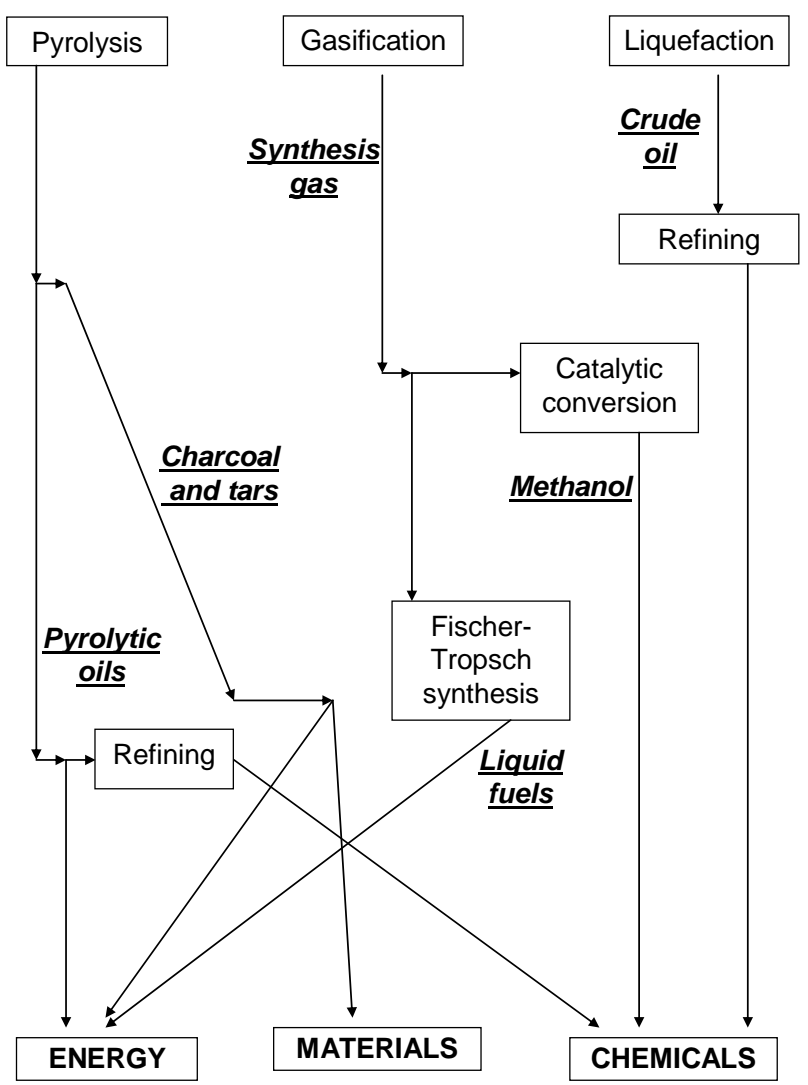

Fig. (1). Simplified scheme of representative alternatives for the thermochemical processing of lignocellulosic raw materials.

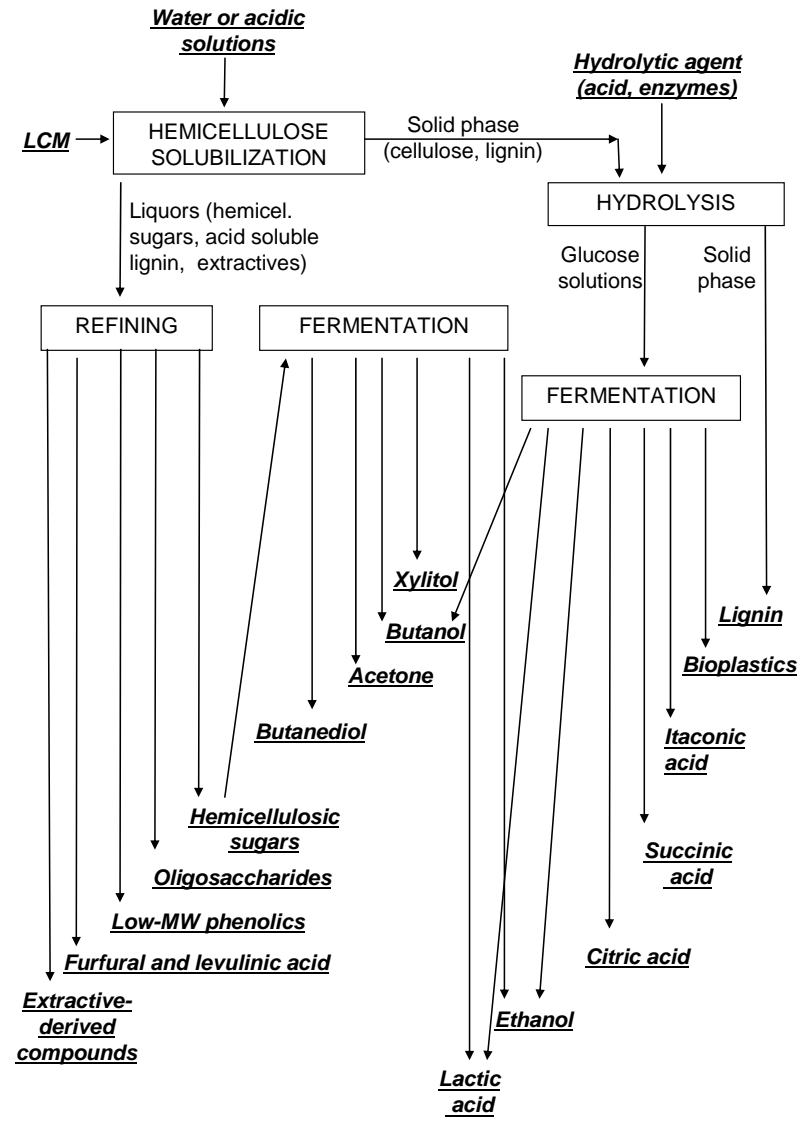

Fig. (2). Simplified scheme of representative alternatives for the processing of lignocellulosic raw materials by means of polysaccharide hydrolysis.

bioplastics, including solvents and polyfunctional organic acids $[26,29]$. The scheme could be completed with the production of other fuels (biogas, biohydrogen) from waste streams of the main process [30]. Additionally, the products listed in Fig. (2) are precursors of a wide variety of chemicals.

Alternatively, the hemicellulose solubilization step presented in Fig. (1) could be replaced by other chemical o physicochemical treatments suitable for rendering the LCM susceptible to enzymatic hydrolysis or for separating lignin from cellulose. Fig. (3) develops this possibility for delignification treatments, which primarily intend to cause lignin solubilization. This philosophy is today followed in pulping (including the sulphite, kraft and organosolv methods). Sulphite mills obtain coproducts from lignin (lignosulfonates) and hemicelluloses (hemicellulosic sugars, acetic acid), which can be employed for commercial purposes. The kraft technology recovers energy from pulping liquors by concentrating and burning both hemicellulose- and lignin- derived compounds, and modern approaches based on the gasification of this stream are underway to improve the overall efficiency [31]. Organosolv pulping is an attractive approach enabling the production of sulphur-free lignin with potential to be used in higher value-added applications. This philosophy is particularly interesting, as it can result in the separation of the three major LCM components (hemicellulose, 


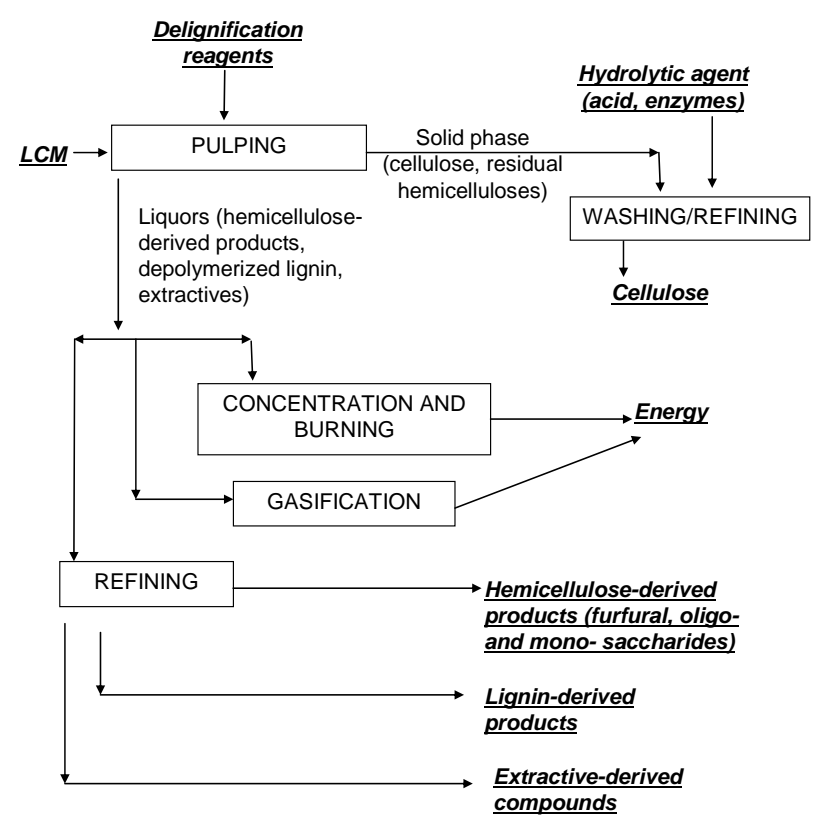

Fig. (3). Simplified scheme of representative alternatives for the processing of lignocellulosic raw materials by means of treatments intending the solubilization of lignin.

cellulose and lignin) into different streams (untouched or as depolymerized products). This philosophy has been developed for Acetosolv pulping (based on the utilization of $\mathrm{HCl}-$ catalyzed, concentrated acetic acid solutions as pulping agent) $[32,33]$. Utilization of ethanol-water mixtures in catalyzed or uncatalyzed media (with a possible preextraction step) followed by enzymatic hydrolysis and manufacture of lignin-derived products has been proposed for obtaining platform chemicals from hardwoods [34], and other processing schemes have been presented for the overall benefit of LCM [35].

Finally, it can be noted that the thermochemical platform and the fractionation technologies based on the separation of hemicelluloses, cellulose and lignin can be complementary. For example, certain types of lignin can be good substrates for liquefaction [28], whereas the production of higher alcohols can be achieved from both methanol (see Fig. 1) and ethanol (see Fig. 2) by catalytic reaction, which can convert a mixture of propanol, isobutanol, and 2-methyl-1-butanol at high yield [36]. Moreover, sugars can be processed into liquid fuels by aqueous phase reforming, a technology suitable for processing both pentoses and hexoses, increasing product yields [37].

\section{MAJOR ISSUES AFFECTING THE DEVELOPMENT OF LCM BIOREFINERIES}

Biorefineries have been considered as a "catch and release" method for using carbon [38]. The development of LCM biorefineries has to be based in well defined objectives, principles and requirements, including:

- ability for fulfilling the needs for energy, chemicals, goods and materials in a sustainable way [38] by means of integration of the production within a single operation [13],
- expanding the use of renewable plant-based materials, opening new revenues for both agricultural and chemical sectors [17], ensuring that the companies can take profit of the value chain from the raw material to the final product [16] and freeing the user from the vagaries of petroleum pricing and availability,

- application of new scientific and technological developments currently underway, which may result in the development of new manufacturing concepts,

- adaptation of the processes to the specific characteristics of the LCM used as raw materials and to the major products,

- achievement of an entire and efficient utilization of the various LCM fractions, process byproducts and waste streams, and use economies of scale, common processing operations, materials, and equipment to drive down all production costs $[9,14]$,

- utilization of traditional and modern technologies [22] for achieving the LCM conversion through multiple processes to yield a number of valuable products respecting the principles of the green chemistry,

- diversification of resources [9] and products, reducing problems and risks derived from supplies and singleproduct commercialization, with particular emphasis on the development of broad based technologies capable of producing families of high value chemicals [13],

- decrease of the overall energy intensity of the biorefinery's unit operations, for example by using energyefficient separation technologies such as membranes [38, 39],

- management of the environmental challenges, particularly the decrease of greenhouse gas emissions [19] and mitigation of global warming [9],

- recovery of maximum value from each fraction of the feedstock at a minimum cost [28],

- increasing the potential to achieve even lower costs in the longer term,

- stimulation of R\&D devoted to application of products from LCM processing [14],

- promoting new markets and applications from LCMderived products [14],

- improvement in economic profitability, which make more attractive new investments in the sector [5]. A recent study [40] has confirmed the viability of ethanol production from LCM under the current conditions.

In conclusion, biorefineries are expected to give sustainable and profitable solutions to our present needs, combining and integrating resources, strategies and technologies to maximize economic and environmental benefits, while minimizing waste and pollution.

For achieving the above objectives, various key challenges have to be solved or overcome [41], including:

- feedstock productivity, cost and availability,

- development of reliable and sufficient supply chains operating at reduced costs [1], 
- development of new agricultural infrastructure for the collection and storage of feedstocks. For example, 35$50 \%$ of the total cost of second-generation ethanol corresponds to the feedstock cost, depending on various geographical factors and the types of systems used for harvesting, collecting, preprocessing, transporting, and handling the material [42]; whereas logistics require a highly efficient supply chain with modularized harvesting and preprocessing equipment suitable diverse feedstocks,

- scaling-up of new technologies, particularly in the cases when there is a relative lack of technology available for feedstock conversion [13], and aspects related to the scale of the process [10],

- reduction of losses in harvesting, collection and storage, and modification of unintended material property changes from field to factory,

- logistic issues, aggravated by the low bulk density of the feedstocks,

- risks derived from capital intensive facilities operating with complex innovative technologies,

- possible integration of multiple processes [4], to utilize the wastes from a mill as raw materials in another,

- development of methodologies for process integration, mathematical optimization and processes evaluation in order to identify the optimal set of products and the best route for producing them [4], providing an interface between simulation and experimental work,

- marketing issues not clearly defined,

- uncertainty about the time to commercialization,

- economic competitivity with alternative production methods.

\section{DEVELOPMENT OF INTEGRATED LCM BIORE- FINERIES}

Pulp mills can be considered as the predecessors of the future integrated biomass refineries, and could be used as a launch point for them [2]. One point of debate is whether the development of biorefineries will be an opportunity or a threat to the pulp and paper industry [42]. It has been considered the any shift to bio-refining could represent an opportunity rather than a threat to the pulp and paper industry [43], and represents an option for improving the business models of many forest product companies [44].

Integrated forest biorefineries present an excellent opportunity for the pulp industries to produce, in addition to valuable cellulose fiber, co-products including fuel grade ethanol and additional energy, where all product lines are highly integrated, are highly energy efficient, and have a minimal or no use of fossil fuel, thus resulting in increased revenue streams and profitability and potentially lower the greenhouse gas emissions $[8,45]$. Sustainable biorefinery strategies are expected to result in an increase of overall profits [44].

Some possibilities suggested for modifying the current pulp mills include:

a. extracting value prior to pulping, from extractives (for example, with water or steam, solvents, or supercritical fluids) [46-48] and/or from hemicelluloses (for example, by conversion into fermentable sugars which could be transformed into chemicals, including xylitol, ethanol and itaconic acid) [49-52]. This latter possibility is specially interesting because in terms of energy recovery from pulping liquors, lignin has a relatively high heating value $(27.0 \mathrm{MJ} / \mathrm{kg})$, but the heating value of hemicelluloses is just about one half of this value, and extracting hemicelluloses prior to pulping could potentially boost the industry [52],

b. possibility of producing monomeric sugars that can be fermented into ethanol [2], and producing bioethanol, biohydrogen and biogas from waste streams or hydrolyzates [30, 53],

c. possibility of converting the lignin-rich fermentation residues and low quality biomass residues into syngas that can be used to produce liquid fuels [2],

d. utilization of lignin for producing chemicals such as organic acids [54],

e. gasifying the biomass or lignin-rich spent pulping liquors for the production of liquid fuels [28],

f. incorporation of new technologies for processing, reaction and separations $[55,56]$, alternatives to classical solvents like supercritical fluids, near-critical and supercritical water and water systems (ionic liquids, biphasic and bio-sourced solvents), microwave treatment, sonochemistry, electrochemistry and photochemistry,

g. recovery of valuable compounds (such as vanillin, syringol, and syringaldehyde) from pulping liquors by new technologies [20,40] or direct production of selected chemicals (levulinic acid, lactic acid),

h. manufacture of chemicals such as by means of depolymerization and dehydration reactions (for example, in nearcritical water) [40],

i. manufacture of advanced materials by fermentation (for example, bioplastics), from cellulose-enriched materials [57] and/or lignin (composites) or cellulose nanocrystals for nanotechnology applications.

\section{ROLE OF HDYROTHERMAL PROCESSING IN LCM BIOREFINERIES}

In the future, the potential exists to build biorefineries that produce high-volume/low-value fuels as well as lowvolume/high-value bioproducts. Some compounds belonging to the latter category can be implemented in biorefineries from extractives, hemicelluloses and easily-hydrolyzable lignin. Owing to this, biomass can also be a source of valuable chemicals, pharmaceuticals and food additives [9].

In the field of extractives, there is a sector developed from pinewood extractives (turpentine, tall oil, etc.), and value can be extracted from waxes and secondary metabolites [58]. Valuable compounds can be obtained for defined feedstocks, such as Miscanthus [59].

Added value products from hemicelluloses and acidsoluble lignin can be extracted from LCM by means of a hydrothermal treatment with hot, compressed water. This possibility has been considered in literature $[9,60]$, and 
could result in a number of benefits. In the following paragraphs, the suitability of a hydrothermal treatment for obtaining bioactive compounds (antioxidants and prebiotic oligosaccharides) is discussed.

Hydrothermal processing of LCM under mild conditions using water or steam results in the selective breakdown of hemicelluloses, leading to liquors containing soluble hemicellulose-derived products and to exhausted solids with enhanced contents of cellulose and lignin. This fraction is suitable for further processing according to the schemes shown in Figs. (1) to (3).

When hydrothermal treatments are performed under mild conditions, the reaction liquors contain sugar oligomers as major products, together with a variety of other compounds, including sugar-degradation products, organic acids, extractives and phenolics. Owing to the complex composition of liquors, refining stages have to be implemented for separating the various types of products. In this work, the attention is focused on two major fractions (oligosaccharides and antioxidants of phenolic nature), even if other valuable products (particularly, derived from extractives) can also be present in liquors.

Refining of liquors usually requires multi-step processing. Solvent extraction with ethyl acetate has been successfully employed as the first stage of purification schemes [61, 62], since saccharides remain in the aqueous phase, whereas non-saccharide compounds (including those of phenolic nature) are transferred to the organic phase. The major types of compounds present in ethyl acetate extracts of hydrothermal hydrolysates have been classified in four categories [63, 64]:

a) sugar-derived compounds, particularly aldehydes from dehydration reactions,

b) phenolic compounds, including alcohols, aldehydes, ketones, benzoic acid and cinnamic acid, which are considered responsible for most of the antioxidant activity of crude extracts,

c) aliphatic fatty acids, and

d) other compounds
Interestingly, the phenolic compounds present in the ethyl ether extract may be considered of natural origin, structure and composition, and show antioxidant activity, providing additional economic value [65].

Part of the phenolics present in liquors from hydrothermal processing of LCM comes from extractives and from the partial depolymerization of lignin and breaking of ligninhemicellulose linkages [66]. The depolymerized lignin fraction include p-substituted phenols (with zero, one or two methoxy groups), aldehydes, acetophenones and carboxylic acids. Ferulic and p-coumaric acids (the most abundant hydroxycinnamic acids) are linked to arabinoxylans or pectins through ester bonds. In hardwoods, condensed tannins (proanthocyanidins) and hydrolyzable ellagitannins make also part of the phenolic fraction [67, 68], whereas acids (gallic, vanillic and ellagic) and aldehydes (syringaldehyde and sinapaldehyde) have been also detected [69].

Reported values of the phenolic content of crude ethyl acetate extracts produced under optimized conditions lie in the range $25-35 \%$ (weight basis), and the factions showed scavenging capacity (for example, against the DPPH and ABTS radicals) according to a concentration dependent pattern. The antioxidant potency of extracts in an emulsion of $\beta$ carotene and linoleic acid was strongly dependent on the concentration. Fig. (4) includes data on the extraction yield, purity and antioxidant activity of fractions obtained by isothermal and non-isothermal processing of selected raw materials in aqueous media [62, 63, 70-72].

Further improvements in antioxidant activity have been achieved by implementing of refining stages, including:

a. gel chromatography in Sephadex LH-20, which yielded fractions with radical scavenging capacity comparable to the reference antioxidant BHA, justified on the basis of a high a phenolic content (about $90 \%$ g gallic acid equivalents/100 g extract) [73],

b. solvent fractionation using a sequence of solvents of increasing polarity and further fractionation of the selected extracts in Sephadex LH-20, which led to fractions whose antioxidant activity was strongly related to their

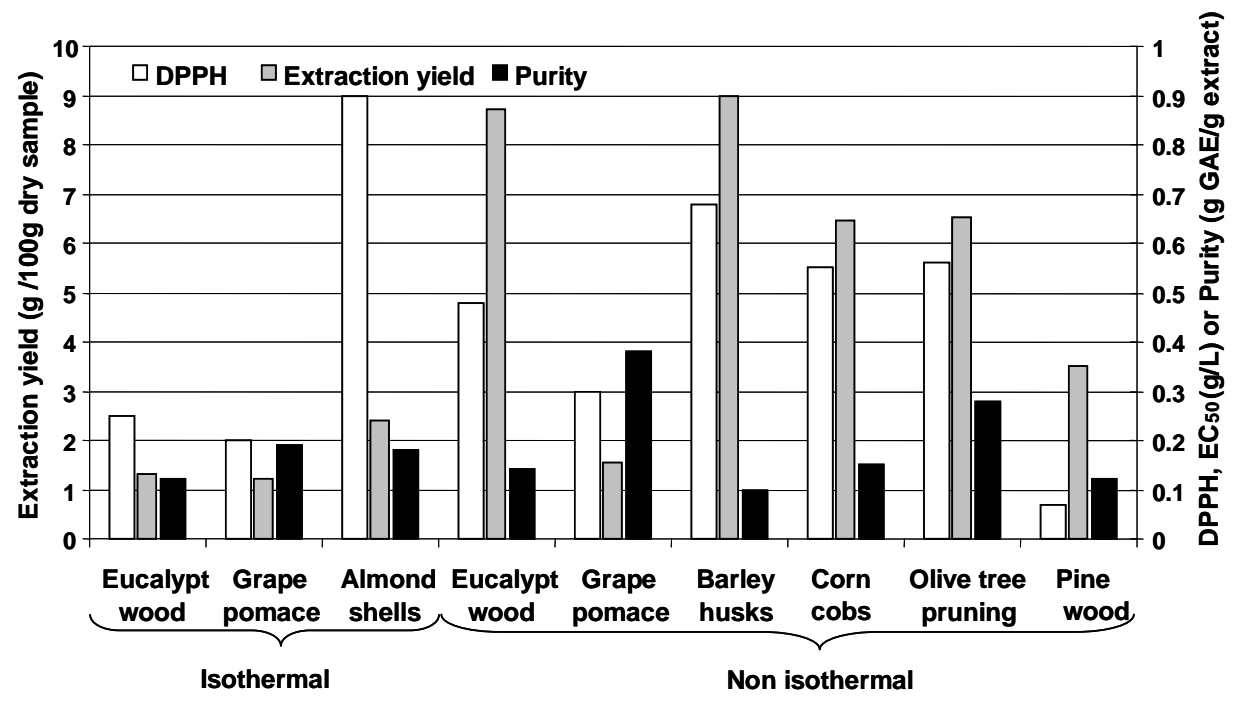

Fig. (4). Yield, antioxidant activity and purity of extracts obtained by autohydrolysis (isothermal/non isothermal)-extraction of selected raw materials. 
phenolic content. Treatments with solvents such as hexane and acetone were suitable to remove non phenolic compounds selectively, and could be employed to increase the phenolic content of isolates [74],

c. adsorption onto polymeric commercial resins and further desorption with ethanol allowed the evaluation of adsorption capacity yields (60-80\%) and purity (almost 50\%) of the recovered fraction. The selectivity of phenolics was limited by the fact that ethanol concentration was the most influential and significant parameter, and elution of sugar-derived compounds was also largely affected by this variable, resulting in co-elution. However, both the purity of extracts and the concentration of the major compounds were significantly enhanced by this separation method [74].

Owing to their ability for preventing the damage caused by reactives species, antioxidants can be useful for prevention and treatment of number diseases. Specific effects have been reported for the following compounds:

- Chlorogenic acid (protection against induced carcinogenesis) [75].

- Syringic and vanillic acid (antiinflamatory activity) [76].

- 3,4-dihydroxybenzaldehyde (inhibition of oncogenic diseases) [77].

- Vanillin (anti-angiogenic, anti-inflammatory and antinociceptive activities) [78].

- Caffeic acid, ellagic acid and ferulic acid (anti-apoptotic activity) [79].

- Gallic acid, caffeic acid, protocatechuic acid (induction of cancer cell apoptosis) [80-82].

- Vanillin and cinnamaldehyde (antimutagenic against spontaneous mutations human cells) [83].

- Protocatechuic acid p-coumaric, caffeic, ferulic, gentisic, syringic and isovanillic acids (anti-inflammatory properties) $[84,85]$.

- Ellagic acid (metal chelating activity suitable for treatment of nickel-induced renal and hepatic biochemical alterations ) [86].

- Gallic acid (skin protective ability) [87].

Concerning the effects of hydrothermal processing on hemicelluloses, the common pattern is the breakdown of polysaccharide chains into short, soluble fragments, that conserve the structural features of the original polymer [88]. The predominant hemicellulose component of hardwoods and many agricultural residues is xylan, whereas softwood hemicelluloses are predomiantly made of glucomannan.

Upon hydrothermal processing, xylan-containg LCM yield soluble oligomers and lower-MW polymers, which can be substituted with O-methyl-uronic acid groups (in the case of hardwoods), arabinose moieties, acetyl groups and esterified phenolic acids (depending on the LCM employed). The molecular weight distribution of the reaction products is usually broad, and depends on the severity of the operational conditions [89]. Usually, the term "oligosaccharides" is reserved for DP in the range 3-10, and compounds of higher molecular weight are referred as "dietary fiber" [90], but the term "oligosaccharide" has also been applied to molecules of higher DP, and this term has been used to refer the set of hemicellulose-derived products obtained in autohydrolysis.

According to literature data, xylan-derived carbohydrates (xylooligosaccharides) behave as prebiotic Non-Digestible Oligosaccharides, a type of compounds of high added value. Similarly, oligosaccharides derived from glucomannan present prebiotic activity [91], and studies for their commercialization are underway.

The manufacture of food-grade oligosaccharides from hydrothermal liquors requires the implementation of exhaustive refining procedures, which are compatible with the ethyl acetate extraction mentioned above for antioxidant recovery. Purification procedures based on individual stages of concentration, precipitation extraction, ion exchange and membrane processing [92] enabled the production of purified hemicellulose oligosaccharides containing up to 90 weight percent of carbohydrates. The remaining $10 \%$ corresponded to phenolic substituents (which provide antioxidant activity to the isolates) and melanoidins (which may confer valuable organoleptic properties to the products) [92, 93].

The major aspects driving the research on the manufacture of oligosaccharides from LCM include:

- the favourable technological properties (heat resistance, stability at acidic $\mathrm{pH}$ ), which enable their utilization as ingredients of functional foods,

- related compounds (linear xylooligosaccharides) are commercial products in Japan (where about 650 ton/yr are produced, about half of the worldwide production, at the highest market price among 13 different types of oligosaccharides) [94], and are under development in the USA,

- recent studies have confirmed their beneficial effects on gastrointestinal health and lipid metabolism in women [95],

- the minimum daily intake for reaching healthy effects is lower than for other oligosaccharides [96],

- their future is promising, based in the high expected demand and further developments (for example, as a part of synbiotic foods), although more knowledge on their healthy effects is needed [97],

- ability for causing beneficial effects additional to the prebiotic ones, including ability for reducing the cholesterol levels [98],

- suitability for utilization in low-calorie diets, and decrease in the constipation incidence [99].

\section{ACKNOWLEDGMENTS}

Authors are grateful to the Spanish Ministry of Science and Innovation for supporting this study, in the framework of the research Project "Properties of new prebiotic food ingredients derived from hemicelluloses" (reference AGL200802072). This Project was partially funded by the FEDER Program of the European Union. Patricia Gullón y Enma Conde wish to thank the Spanish Ministry of Education and Science for Their "Formación del Profesorado Universitario" research grants. 


\section{REFERENCES}

[1] Clark JH. Green chemistry for the second generation biorefinery sustainable chemical manufacturing based on biomass. J Chem Technol Biotechnol 2007; 82(7): 603-9.

[2] Kelley SS. Lignocellulosic biorefineries: reality, hype, or something in between? In: ACS Symposium Series 2007; 954(Materials, Chemicals, and Energy from Forest Biomass): 31-47.

[3] Stocker M. Biofuels and biomass-to-liquid fuels in the biorefinery: catalytic conversion of lignocellulosic biomass using porous materials. Angew Chem Int Ed 2008; 47(48): 9200-211.

[4] Octave S, Thomas D. Biorefinery: Toward an industrial metabolism. Biochimie 2009; 91(6): 659-64.

[5] Bajus M. Biofuels second generation. Pet Coal 2008; 50(3): 27-48.

[6] Jenkins T. Toward a biobased economy: examples from the UK. Biofuels Bioprod Biorefin 2008; 2(2): 133-43.

[7] Cheng S, Zhu S. Lignocellulosic feedstock biorefinery -the future of the chemical and energy industry. BioResources 2009; 4(2): 456-7.

[8] van Heiningen A. Converting a kraft pulp mill into an integrated forest products biorefinery. In: Annual Meeting Preprints - Pulp and Paper Technical Association of Canada, 92nd, Montreal, QC, Canada 2006; pp. 167-76.

[9] Briens C, Piskorz J, Berruti F. Biomass valorization for fuel and chemicals production - a review. Int J Chem Reactor Eng 2008; 6 : R2.

[10] Lange JP. Lignocellulose conversion: an introduction to chemistry, process and economics. Biofuels Bioprod Biorefin 2007; 1(1): 3948.

[11] Pye EK, Armiger WB, Winner SR, Berlin A. High yielding biorefining using Organosolv processing. In: AIChE Annual Meeting, Conference Proceedings, Philadelphia, PA, United States, 2000; 39/1-39/6

[12] Erickson JC. Overview of thermochemical biorefinery technologies. Int Sugar J 2007; 109(1299): 163-164, 166, 168-170, 172-173.

[13] Bozell JJ. Feedstocks for the future - biorefinery production of chemicals from renewable carbon. Clean Soil Air Water 2008; 36(8): 641-7.

[14] Zhang YH. Reviving the carbohydrate economy via multi-product lignocellulose biorefineries. J Ind Microbiol Biotechnol 2008; 35(5): 367-75

[15] Koutinas AA, Du C, Wang RH, Webb C. Production of chemicals from biomass. In: Introduction to Chemicals from Biomass. John Wiley \& Sons: USA 2008; pp. 77-101.

[16] van Haveren J, Scott EL, Sanders J. Bulk chemicals from biomass. Biofuels Bioprod Biorefin 2008; 2: 41-57.

[17] Sanders JPM, Annevelink B, van der Hoeven D. The development of biocommodities and the role of North West European ports in biomass chains. Biofuels Bioprod Biorefin 2009; 3(3): 395-409.

[18] Peck P, Bennett SJ, Bissett-Amess R, Lenhart J, Mozaffarian H. Examining understanding, acceptance, and support for the biorefinery concept among EU policy-makers. Biofuels Bioprod Biorefin 2009; 3(3): 361-83.

[19] Uihlein A, Schebek L. Environmental impacts of a lignocellulose feedstock biorefinery system: An assessment. Biomass Bioenerg 2009; 33(5): 793-802.

[20] Kamm B, Kamm M. The concept of a biorefinery - production of platform chemicals and final products. Chem Ing Tech 2007; 79(5): 592-603.

[21] Kamm B, Schoenicke P, Kamm M. Biorefining of green biomass technical and energetic considerations. Clean Soil Air Water 2009; 37(1): 27-30.

[22] Ragauskas AJ, Williams CK, Davison BH, et al. The path forward for biofuels and biomaterials. Science 2006; 311: 484-9.

[23] Manzer L. Recent developments in the conversion of biomass to renewable fuels and chemicals. In: 237th ACS National Meeting, Salt Lake City, UT, United States 2009

[24] Demirbas A. Biorefineries: current activities and future developments. Energy Convers Manage 2009; 50(11): 2782-801.

[25] Sousa L C, Chundawat Shishir PS, Balan V, Dale BE. 'Cradle-tograve' assessment of existing lignocellulose pretreatment technologies. Curr Opin Biotechnol 2009; 20(3): 339-47.

[26] Katzen R, Schell DJ. Lignocellulosic feedstock biorefinery: history and plant development for biomass hydrolysis. In: Kamm G, Gruber P, Kamm M, Eds. Biorefineries-Industrial Processes and Products: Status Quo and Future Directions. Wiley-VCH: Weiheim 2006: vol. 1: pp. 129-38.
[27] Fitzpatrick SW. The Biofine process: A biorefinery concept based on thermochemical conversion of biomass. In: 227th ACS National Meeting, Anaheim, CA, United States, 200, 2004.

[28] Zhang B, von Keitz M, Valentas K. Maximizing the liquid fuel yield in a biorefining process. Biotechnol Bioeng 2008; 101(5): 903-12.

[29] Zverlov VV, Berezina O, Velikodvorskaya GA, Schwarz WH. Bacterial acetone and butanol production by industrial fermentation in the Soviet Union: use of hydrolyzed agricultural waste for biorefinery. Appl Microbiol Biotechnol 2006; 71(5): 587-97.

[30] Kaparaju P, Serrano M, Thomsen AB, Kongjan P, Angelidaki I Bioethanol, biohydrogen and gas production from wheat straw in a biorefinery concept. Biores Technol 2009; 100(9): 2562-68.

[31] Larson ED, Consonni S, Katofsky RE, Iisa K, Frederick WJ. An assessment of gasification-based biorefining at kraft pulp and paper mills in the United States, Part B: results. Tappi J 2009; 8(1): 2735.

[32] Vila C, Santos V, Parajó JC. Recovery of lignin and furfural from acetic acid-water-HCl pulping liquors. Biores Technol 2003; 90(3): $339-44$.

[33] Vila C, Santos V, Parajó JC. Simulation of an organosolv pulping process: generalized material balances and design calculations. Ind Eng Chem Res 2003; 42(2): 349-56.

[34] Saake B, Schreiber A, Puls J. Platform chemicals from a hardwood biorefinery. In: 237th ACS National Meeting, Salt Lake City, UT, United States 2009.

[35] Delmas M. Vegetal refining and agrichemistry. Chem Eng Technol 2008; 31(5): 792-7.

[36] Olson ES, Sharma RK, Aulich TR. Higher-alcohols biorefinery: Improvement of catalyst for ethanol conversion. Appl Biochem Biotechnol 2004; (113-116): 913-32.

[37] Blommel PG, Keenan,GR, Rozmiarek RT, Cortright RD. Catalytic conversion of sugar into conventional gasoline, diesel, jet fuel, and other hydrocarbons. Int Sugar J 2008; 110(1319): 672-9.

[38] Amidon TE, Shijie L. Water-based woody biorefinery. Biotech Adv 2009; 27(5): 542-50.

[39] Novalin S, Zweckmair T. Renewable resources - green biorefinery: separation of valuable substances from fluid-fractions by means of membrane technology. Biofuels Bioprod Biorefin 2009; 3(1): 20-7.

[40] Huang HJ, Ramaswamy S, Al-Dajani WW Tschirner U, Cairncross RA. Techno-economic analysis of lignocellulose to fuel ethanol biorefinery. In: AIChE Annual Meeting, San Francisco, CA, United States 2006; 595f/1-595f/3.

[41] Tacke T. Chemicals from biomass. DGMK Tagungsbericht 2008; 3: 81-8.

[42] Covey G, Grist, S. What Is the Role for Biorefineries? In: 62nd APPITA Annual Conference and Exhibition, Rotorua, New Zealand Conference Technical Papers. 2008; pp. 1-18.

[43] Hess JR, Wright CT, Kenney KL. Cellulosic biomass feedstocks and logistics for ethanol production. Biofuels Bioprod Biorefin 2007; 1(3): 181-90

[44] Chambost V, McNutt J, Stuart PR. Guided tour: implementing the forest biorefinery (FBR) at existing pulp and paper mills. Pulp Paper Can 2008; 109(7/8): 19-27.

[45] Huang HJ, Ramaswamy S, Al-Dajani WW, Tschirner U. Process modeling and analysis of pulp mill-based integrated biorefinery with hemicellulose pre-extraction for ethanol production: a comparative study. Bioresour Technol 2010; 10(2): 624-31.

[46] de Jong E, van Re Rene, van Tuil R, Elbersen W. Biorefineries for the chemical industry - a Dutch point of view. In: Kamm B, Gruber P, Kamm M , Eds. Biorefineries-Industrial Processes and Products: Status Quo and Future Directions. Wiley-VCH, Weiheim 2006; 1: 85-111.

[47] Deswarte FEI, Clark James H, Wilson AJ, et al. Toward an integrated straw-based biorefinery. Biofuels Bioprod Biorefin 2007 1(4): $245-54$

[48] Liu J, Lin L, Pang C, et al. Poplar woodchip as a biorefinery feedstock-prehydrolysis with formic/acetic acid/water system, xylito production from hydrolysate and kraft pulping of residual woodchips. J Biobased Mat Bioenerg 2009; 3(1): 37-45.

[49] Amidon TE. The biorefinery in New York: woody biomass into commercial ethanol. Pulp Pap Can 2006; 107(6): 47-50.

[50] Carvalheiro F, Duarte, LC, Girio, FM. Hemicellulose biorefineries: a review on biomass pretreatments. J Sci Ind Res 2008; 67(11) 849-64. 
[51] Eriksen D, Sullivan RP, Zhao H. Toward the development of a cost-effective process for xylitol production. In: 238th ACS National Meeting, Washington, DC, United States, BIOT-271, 2009.

[52] Graham LB, O-Farrill A, Genco JM, Fort RC, Cole BJW. Comparison of acid and enzymatic hydrolysis of hardwood hemicelluloses for the development on an integrated forest biorefinery. In: 235th ACS National Meeting, New Orleans, LA, United States, CELL-218, 2008.

[53] Kaparaju P, Serrano M, Angelidaki I. Effect of reactor configuration on biogas production from wheat straw hydrolysate. Bioresour Technol 2009; 100(24): 6317-23.

[54] Hasegawa I, Inoue Y, Yasukawa T, Mae K. Selective production of organic acids from lignin with hydrogen peroxide under hydrothermal conditions. In: 238th ACS National Meeting, Washington, DC, United States, August 16-20, FUEL-093, 2009.

[55] Eckert CA, Liotta CL, Ragauskas AJ,et al. Tunable solvents for fine chemicals from the biorefinery. In: Preprints of Symposia American Chemical Society, Division of Fuel Chemistry 2006; vol. 51, issue 2: pp. 436-7.

[56] Eckert C, Liotta C, Ragauskas A, et al. Tunable solvents for fine chemicals from the biorefinery. Green Chem 2007; 9(6): 545-8.

[57] Vila C, Campos AR, Cristovao C, Cunha AM, Santos V, Parajó JC. Sustainable biocomposites based on autohydrolysis of lignocellulosic substrates. Compos Sci Technol 2008; 68(3-4): 944-52.

[58] Uppugundla N, Engelberth A, Vandhana Ravindranath S, et al. Switchgrass Water extracts: extraction, separation and biological activity of rutin and quercitrin. J Agric Food Chem 2009; 57(17): 7763-70.

[59] Villaverde JJ, Domingues RMA, Freire CSR, et al. Miscanthus x giganteus extractives: A source of valuable phenolic compounds and sterols. J Agric Food Chem 2009; 57(9): 3626-31.

[60] Yoon SH, Van Heiningen A. Kraft pulping and papermaking properties of hot-water pre-extracted loblolly pine in an integrated forest products biorefinery. Tappi J 2008; 7(7): 22-7.

[61] Frazer FR, McCaskey TA. Wood hydrolyzate treatments for improved fermentation of wood sugars to 2,3-butanediol. Biomass 1989; 18(1): 31-42.

[62] Garrote G, Cruz JM, Domínguez H, Parajó JC. Non-isothermal autohydrolysis of barley husks: Product distribution and antioxidant activity of ethyl acetate soluble fractions. J Food Eng 2008; 84: 544-52.

[63] Garrote G, Cruz JM, Domínguez H, Parajó JC. Valorisation of waste fractions from autohydrolysis of selected lignocellulosic materials. J Chem Technol Biotechnol 2003; 78: 392-8.

[64] Garrote G, Cruz JM, Moure A, Domínguez H, Parajó JC. Antioxidant activity of byproducts from the hydrolytic processing of selected lignocellulosic materials. Trends Food Sci Technol 2004; 15(3-4): 191-200

[65] Cruz JM, Domínguez JM, Domínguez H, Parajó JC. Solvent extraction of hemicellulosic wood hydrolysates: a procedure useful for obtaining both detoxified fermentation media and polyphenols with antioxidant activity. Food Chem 1999; 67: 147-53.

[66] Felizón B, Fernández-Bolaños J, Heredia A, Guillén R. Steamexplosion pretreatment of olive cake. JAOCS 2000; 77(1): 15-22.

[67] Cadahía E, Varea S, Muñoz L, Fernández de Simón B, GarcíaVallejo MC. Evolution of ellagitannins in Spanish, French, and American oak woods during natural seasoning and toasting. J Agric Food Chem 2001; 49 (8): 3677-84.

[68] Helm RF, Ranatunga TD, Chandra M. Lignin-hydrolyzable tannin interaction in wood. J Agric Food Chem 1997; 45(8): 3100-3106

[69] Conde E, Cadahía E, Garcia-Vallejo MC. HPLC analysis of flavonoids and phenolic acids and aldehydes in Eucalyptus spp. Chromatography 1995; 41(5-6): 657-60.

[70] Conde E, Cara C, Moure A, Ruiz E, Castro E, Domínguez H. Antioxidant activity of the phenolic compounds released by hydrothermal treatments of olive tree pruning. Food Chem 2009; 114(3): 806-12.

[71] Moure A, Domínguez H, Parajó JC. Antioxidant activity of liquors from aqueous treatments of Pinus radiata wood. Wood Sci Technol 2005; 39: 129-39.

[72] Moure A, Pazos M, Medina I, Domínguez H, Parajó JC. Antioxidant activity of extracts produced by solvent extraction of almond shells acid hydrolysates. Food Chem 2007; 101: 193-201.

[73] Cruz JM. Domínguez H, Parajó JC. Anti-oxidant activity of isolates from acid hydrolysates of Eucalyptus globulus wood. Food Chem 2005; 90: 503-11.
[74] Conde E, Moure A, Domínguez H, Parajó JC. Fractionation of antioxidants from autohydrolysis of barley husks. J Agric Food Chem 2008a; 56(22): 10651-9.

[75] Feng R, Lu Y, Bowman LL, Qian Y, Castranova V, Ding M.. Inhibition of ctivator protein-1, NF-kappaB, and MAPKs and induction of phase 2 detoxifying nzyme activity by chlorogenic acid. J Biol Chem 2005; 280: 27888-95.

[76] Itoh A, Isoda K, Kondoh M, et al. Hepatoprotective effect of syringic acid and vanillic acid on concanavalin A-induced liver injury. Biol Pharm Bull 2009; 32(7): 1215-9.

[77] Lee BH, Yoon SH, Kim YS, Kim SK, Moon BJ, Bae YS. Apoptotic cell death through inhibition of protein kinase CKII activity by 3,4-dihydroxybenzaldehyde purified from Xanthium strumarium. Nat Prod Res 2008; 22(16): 1441-50.

[78] Lim EJ, Kang HJ, Jung HJ, Song YS, Lim CJ, Park EH. Antiangiogenic, anti-inflammatory and anti-nociceptive activities of vanillin in ICR mice. Biomol Therapeut 2008; 16(2): 132-6.

[79] Khanduja KL, Avti PK, Kumar S, Mittal N, Sohi KK, Pathak CM. Anti-apoptotic activity of caffeic acid, ellagic acid and ferulic acid in normal human peripheral blood mononuclear cells: A Bcl-2 independent mechanism. Biochim Biophys Acta 2006; 1760(2): 2839.

[80] Chung TW, Moon SK, Chang YC, et al. Novel and therapeutic effect of caffeic acid and caffeic acid phenyl ester on hepatocarcinoma cells: complete regression of hepatoma growth and metastasis by dual mechanism. FASEB J 2004; 18: 1670-81.

[81] Qin S, Chock PB. Bruton's tyrosine kinase is essential for hydrogen peroxide-induced calcium signalling. Biochemistry 2001; 40: 808591.

[82] Yin MC, Lin CC, Wu HC, Tsao SM, Hsu CK. Apoptotic effects of protocatechuic acid in human breast, lung, liver, cervix, and prostate cancer cells: potential mechanisms of action. J Agric Food Chem 2009; 57(14): 6468-73.

[83] King AA, Shaughnessy DT, Mure K, et al. Antimutagenicity of cinnamaldehyde and vanillin in human cells: Global gene expression and possible role of DNA damage and repair. Mutat Res 2007; 616(1-2): 60-9.

[84] Cartron E, Carbonneau MA, Fouret G, Descomps B, Leger CL. Specific anti-oxidant activity of caffeoyl derivatives and other natural phenolic compounds: LDL protection against oxidation and decrease in the pro-inflammatory lysophosphatidylcholine production. J Nat Prod 2001; 64: 480-6.

[85] Fernández MA, Saenz MT, García M. Antiinflammatory activity in rats and mice of phenolic acids isolated from Scrophularia frutescens. J Pharm Pharmacol 1998; 50: 1183-6.

[86] Ahmed S, Rahman A, Saleem M, Athar M Sultana S. Ellagic acid ameliorates nickel induced biochemical alterations: diminution of oxidative stress. Hum Exp Toxicol 1999; 18: 691-8.

[87] Kim YJ. Antimelanogenic and antioxidant properties of gallic acid Biol Pharm Bull 2007; 30(6): 1052-5.

[88] Kabel MA, Carvalheiro F, Garrote G, et al. Hydrothermally treated xylan rich by-products yield different classes of xylooligosaccharides. Carbohydr Polym 2002; 50(1): 47-56.

[89] Vegas R, Kabel M, Schols HA, Alonso JL, Parajó JC. Hydrothermal processing of rice husks: effects of severity on product distribution. J Chem Technol Biotechnol 2008; 83(7): 965-72.

[90] Tungland BC, Meyer D. Nondigestible oligo- and polysaccharides (dietary fiber): their physiology and role in human health and food. Comp Rev Food Sci Food Safety 2002; 3:73-92.

[91] Al-Ghazzewi FH, Khanna S, Tester RF, Piggott J. The potential use of hydrolysed konjac glucomannan as a prebiotic. J Sci Food Agric 2007; 87(9): 1758-1766

[92] Vegas R, Luque S, Alvarez JR, Alonso JL, Domínguez H, Parajó JC. Membrane-assisted processing of xylo-oligosaccharidecontaining liquors. J. Agric Food Chem 2006; 54: 5430-6.

[93] Vegas R, Alonso JL, Domínguez H, Parajó J.C. Manufacture and refining of oligosaccharides from industrial solid wastes. Ind Eng Chem Res 2005; 44: 614-20.

[94] Taniguchi H. Carbohydrate research and industry in Japan and the Japanese Society of Applied Glycoscience. Starch/Starke 2004; 56 (1): $1-5$.

[95] Na MH, Kim WK. Effects of xylooligosaccharide intake on fecal bifidobacteria, lactic acid and lipid metabolism in Korean young women. Korean Nutr Soc 2007; 40(2): 154-61. 
[96] Nakakuki T. Present Status and Future Prospects of Functional Oligosaccharide Development in Japan. J Appl Glycosci 2005; 52(3): 267-71

[97] Stanton C, Gardiner G, Meehan H, Collins K, Fitzgerald G, Lynch PB. Market potential for probiotics. Am J Clin Nutr 2001; 73: S476-84

[98] Martino F, Martino E, Morrone F, Carnevali E, Forcone R, Niglio $\mathrm{T}$. Effect of dietary supplementation with glucomannan on plasma total cholesterol and low density lipoprotein cholesterol in hypercholesterolemic children. Nutr Metab Cardiovasc Dis 2005; 15(3): 174-80.

[99] Loening-Baucke V, Miele E, Staiano A. Fiber (glucomannan) is beneficial in the treatment of childhood constitpation. Pediatrics 2004; 113: 25 .

(C) Gullón et al.; Licensee Bentham Open.

This is an open access article licensed under the terms of the Creative Commons Attribution Non-Commercial License (http://creativecommons.org/licenses/ by-nc/3.0/) which permits unrestricted, non-commercial use, distribution and reproduction in any medium, provided the work is properly cited. 